\title{
Once-daily milking of dairy cows: a review of recent French experiments 1
}

\author{
Bernard RÉMOND ${ }^{a *}$, Dominique POMIÈs ${ }^{b}$
}

\begin{abstract}
${ }^{\text {a }}$ Unité Élevage et Production des Ruminants (supported by the Institut National de la Recherche Agronomique [INRA]), École Nationale d'Ingénieurs des Travaux Agricoles, BP 35, 63370 Lempdes, France

b Unité de Recherche sur les Herbivores, INRA Clermont-Ferrand/Theix, 63122 Saint-Genès-Champanelle, France
\end{abstract}

(Received 5 April 2005; accepted 2 August 2005)

\begin{abstract}
Once-daily milking (ODM) implemented in the declining phase of lactation for up to at least 10 weeks reduced milk yield by $20-30 \%$, according to the trial, from the first day. Milk loss $(\%)$ exhibited a high between-cow variability and was unrelated to the milk yield $(\mathrm{kg})$ of the cows. When twice-daily milking (TDM) was resumed, milk yield recovered completely following implementation of ODM for a few days, but reached only about $90 \%$ of the yield of TDM cows following implementation of ODM for 8-10 weeks. When implemented from calving, ODM had a progressively higher negative impact (a decrease of between 30 and 50\%), which was more pronounced in primiparous cows than in multiparous cows. The residual loss (\%), once TDM resumed, was generally higher than in the declining phase. When ODM was implemented during three successive lactations, there was no between-lactation effect. ODM increased fat and protein content in milk and decreased lactose content by an average $2.8,1.5$ and $1.5 \mathrm{~g} \cdot \mathrm{L}^{-1}$, respectively. The casein/protein ratio was reduced (by $1.8 \%$ on average). Resumption of twice-daily milking cancelled these modifications within a few days. Protease activity in milk tended to increase, whereas lipase activity tended to decrease with ODM. Free fatty acid content was reduced significantly with ODM. Implementation of ODM did not significantly modify feed intake of the cows in the short term (up to 6-8 weeks), but tended to decrease it thereafter. The quality of cheese manufactured from TDM or ODM milks were similar. ODM implementation led to an improved nutritional status of the cows, as appreciated by changes of live weight, body condition score, or calculated energy balance. It also improved reproduction parameters. The cows adapted quickly to ODM (within a few days). ODM increased the somatic cell count in milk without impact on mastitis infection incidence in the short term. When implemented throughout lactation during which cows were partly in barn conditions, ODM increased mastitis infection incidence in 2 out of 3 trials.
\end{abstract}

once-daily milking / cows / adaptation / performance / review

\footnotetext{
* Corresponding author: remond@enitac.fr

${ }^{1}$ Invited paper at the 55th annual meeting of the European Association of Animal Production held in Bled on 5-9 September 2004, Slovenia.
} 
Résumé - La traite une fois par jour des vaches laitières : revue des récents essais français. Utilisée pendant la phase descendante de la lactation pour des durées allant jusqu'à 10 semaines, la traite une fois par jour (monotraite) a réduit la quantité de lait produite de 20 à $30 \%$ selon les essais, dès le $1^{\mathrm{er}}$ jour. Cette réduction (\%) a présenté une variation individuelle élevée mais indépendante du niveau de production laitière des vaches. Quand la traite deux fois par jour (traite bi-quotidienne) a été reprise, les vaches ont complètement recouvré leur production de lait lorsque la monotraite n'avait duré que quelques jours, mais elles n'en ont recouvré que $90 \%$ après une monotraite de 8 à 10 semaines. Mise en œuvre dès le début de la lactation, la monotraite a eu un impact négatif progressif, plus élevé que pendant la phase descendante (diminution de 30 à $50 \%$ ), et plus prononcé chez les vaches primipares que chez les multipares. Quand la monotraite a été utilisée de façon continue pendant les 3 premières lactations, elle n'a pas eu d'effet cumulatif d'une lactation à la suivante. La monotraite a accru les teneurs du lait en matières grasses et en protéines, et elle a diminué la teneur en lactose, de respectivement $2,8 \mathrm{~g} \cdot \mathrm{L}^{-1}, 1,5 \mathrm{~g} \cdot \mathrm{L}^{-1}$ et $1,5 \mathrm{~g} \cdot \mathrm{L}^{-1}$. Le rapport caséines/protéines a été réduit de 1,8 point p. 100 en moyenne. La reprise de la traite bi-quotidienne a annulé ces modifications en quelques jours. L'activité protéasique a eu tendance à augmenter avec la monotraite alors que l'activité de la lipoprotéine lipase a eu tendance à diminuer. La teneur du lait en acides gras libres a été significativement réduite par la monotraite. La mise en œuvre de la monotraite n'a pas modifié significativement les quantités d'aliments ingérées par les vaches, à court terme (68 semaines), mais elle a eu tendance à les accroître à plus long terme. Les caractéristiques du fromage fabriqué avec du lait de vaches soumises à la monotraite ou à la traite bi-quotidienne ont été semblables. La monotraite a amélioré l'état nutritionnel des vaches, apprécié par le changement de poids vif, la note d'état corporel ou le bilan énergétique calculé. Elle a aussi amélioré les paramètres de la reproduction. Les vaches se sont habituées en quelques jours à la monotraite. Celle-ci a accru le nombre de cellules dans le lait (nombre par $\mathrm{mL}$ ) sans impact, à court terme, sur l'incidence de mammites. Quand la monotraite a été utilisée pendant toute la lactation, dont une partie se déroulait en étable, elle a accru l'incidence des mammites dans deux des trois essais réalisés.

une traite par jour / vaches / adaptation / performances / revue

\section{INTRODUCTION}

Milking is the primary activity of the dairy producer. It accounts for approximately half of his/her routine labour and structures his/ her daily timetable. The workload associated with milking has been largely reduced since hand-milking, but milking frequency (almost always twice-daily in non-robotised milking) and times at which cows are milked have largely remained unchanged.

Dairy production has undergone major changes in the EEC countries, particularly over the last two decades, under the combined influences of European and world agricultural and trade policies and general evolutions in agriculture and society: strict quotas, since 1984 , on the quantity of milk that could be sold by each farmer (requiring strict control of milk production through the entire campaign), prescribed decreases in milk price (requiring reduced production costs), increases in the number of cows per farm and per worker, the growing aspira- tions of dairy producers towards less constraints and extended leisure time (which are largely hampered by twice-daily milking [TDM] practice), etc. The implementation of once-daily milking (ODM) for a variable length of time (from a few days to the entire lactation period) could help milkproducers to contend with these issues, provided that cows are able to satisfactorily adapt to this milking regime.

So far, ODM has only been implemented as a regular practice during the late stage of cow lactation in New Zealand. Thus, most of the research on this management strategy has been carried out (see reviews by Davis et al. [14], and Stelwagen [39]) in conditions that are largely different from those prevailing in Europe, such as lower milk yield per cow, seasonality of calving (late winter) and drying-off (late autumn), permanent management at pasture and without limitations on milk production. The potential benefits of ODM for the milk producers in our country have encouraged us to 
progress the studies undertaken in New Zealand in the early nineteen-eighties, but in local conditions. This paper is aimed at summarising the results recorded in recent French experiments.

\section{ORIGIN OF THE DATA}

The data on the performance of cows subjected to ODM used in this review were recorded in 11 trials performed over the last 8 years, including one trial covering 6 years and still in progress [8]. The results from nine of the trials have been at least partly published [28, 29, 31-35]. Ten of the trials were carried out in the facilities of the INRA Centre of Clermont-Ferrand/Theix, and the remaining trial [17] was undertaken at the experimental farm of the Finistère Chamber of Agriculture (Brittany). The objectives and experimental protocols (including duration, number of cows, experimental design) varied widely between trials, but all included a TDM group as a control treatment. Most of the cows in experimentation were of the Holstein breed, but Montbéliarde and Tarentaise cows were also included in five of the trials. The following measurements were collected on an individual cow basis in the trials managed at INRA facilities: milk yield at each milking, milk composition (fat, protein, lactose and somatic cell count [SCC]) in samples at each milking of at least one day weekly, feed intake (indoor only) on 4 days per week. The frequency of the other measurements and the methods used are described in the relevant publications.

\section{MILK PRODUCTION}

\subsection{Milk yield}

When implemented during the declining phase of lactation, ODM decreased milk yield from the first day by between $20 \%$ and $30 \%$, according to the trial (Fig. 1). In the literature, reported milk yield losses with

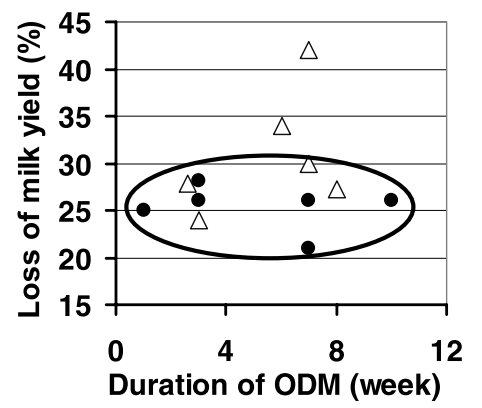

Figure 1. Effect of the duration (in weeks) of the period of once daily milking (ODM) on the loss of milk yield $(\%)$ during that period for ODM implemented at different stages of lactation ( $\Delta$ from calving; - from peak of lactation or later) (from $[8,28,29,31,32,34-$ $36])$.

ODM range from $38 \%$ [41] at the peak of lactation to $7-15 \%[5,6,23,40,42]$. Our results were similar to the losses observed by Farr et al. [15] (26\%), Knight and Dewhurst [21] (23\%) and O'Brien et al. [27] $(30 \%)$. As shown in Figure 1, this reduction in milk yield did not depend on the duration of ODM application, at least up to ten weeks.

Milk loss was higher when ODM was implemented during the first weeks of the descending phase of lactation (from the 6th week) than in mid-lactation (16th and 27th week) $\left(7.1 \mathrm{~kg} \cdot \mathrm{d}^{-1}, 4.9 \mathrm{~kg} \cdot \mathrm{d}^{-1}\right.$ and $3.9 \mathrm{~kg} \cdot \mathrm{d}^{-1}$, respectively $(P<0.01)$ [29]. In relative values, these similar losses in milk yield $(28 \%$, $25 \%$ and $24 \%$ for weeks 6,16 and 27 , respectively) tended to decrease slightly, but less than previously observed by Carruthers et al. [7] (loss of 10-28\% in early-mid lactation vs. $9-13 \%$ in late lactation) and Stelwagen and Knight [41] (loss of $38 \%$ around the peak of lactation vs. $28 \%$ in late lactation).

When ODM was implemented from calving, it had a progressively negative effect on milk yield (Fig. 2), as shown earlier [10]. Milk loss $\left(\mathrm{kg} \cdot \mathrm{d}^{-1}\right.$ or \%) peaked in the second to third month of lactation and then 


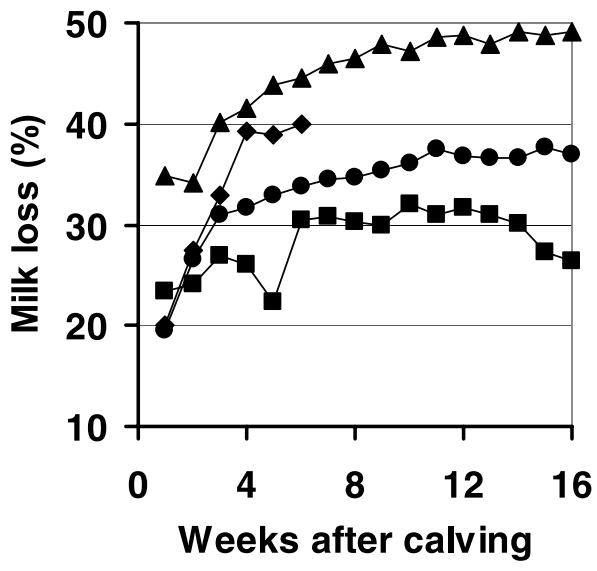

Figure 2. Effect of once daily milking from calving on the evolution of the loss of milk (expressed as \% of the milk yield of the control group milked twice daily) (from [8] [ $\mathbf{\Lambda}: 87$ ODM + TDM primiparous cows; $\bullet: 58$ multiparous cows]; from [31] [ $\$$ : 22 multiparous cows]; from [35] [ $\mathbf{\square} 16$ multiparous cows]).

decreased $\left(\mathrm{kg} \cdot \mathrm{d}^{-1}\right)$ or plateaued $(\%)$. When ODM was applied for at least 4-5 weeks from calving, its deleterious impact on milk yield was generally higher and more variable than when implemented in the declining phase of lactation (Fig. 1).

Once TDM was resumed, milk yield recovered rapidly (essentially in the first week), but generally not totally (Fig. 3). Residual milk loss decreased with shorter periods of ODM: loss was $2.6 \%$ (NS) after one week of ODM [34], but approximately $10 \%$ after $7-10$ weeks of ODM ([28, 29, 33]; Fig. 3). This impact of duration of ODM was particularly obvious in early lactation [31]. Complete milk recovery after 1 week ODM has been previously observed [21], whereas no recovery at all was shown after 5 months of ODM [10]. Residual milk loss also decreased since ODM was implemented at later stages of lactation (residual loss of $1.8 \mathrm{~kg}, 1.2 \mathrm{~kg}$ and $0.3 \mathrm{~kg}$ for ODM implementation (duration of 3 weeks) at weeks 9, 19 and 30 of lactation, respec- tively, i.e. corresponding to a loss of $8.0 \%$, $6.7 \%$ and $2.4 \% ; P<0.01$ [29]).

When ODM was implemented throughout lactation, the lactation curve was roughly similar to that recorded for TDM, but milk yield was lower by $30 \%$ [35] to $47 \%$ [8] for ODM cows. These losses are within the range previously observed over a complete lactation period ( $50 \%$ for Claesson et al. [10]; 35\% for both Cooper [11] and Holmes et al. [18]). The peak of lactation was reached earlier (by 1-2 weeks; [8, 35]) than in TDM cows, and the lactation was shortened by $2-3$ weeks $[17,35]$, as reported previously [10, 11, 25].

Several physiological mechanisms have been proposed to explain the reduction of milk yield induced by ODM, such as the secretion in milk of a protein capable of inhibiting milk secretion [46] and the increased permeability of tight junctions of the mammary parenchyma [44]. Davis et al. [14] have proposed an integrating scheme in which the trigger of the reduction in milk secretion is the engorgement of mammary alveoli, which in turn changes gene expression in the secretory cells, leading to accelerated quiescence and/or death. A lower persistency of milk yield would be expected.

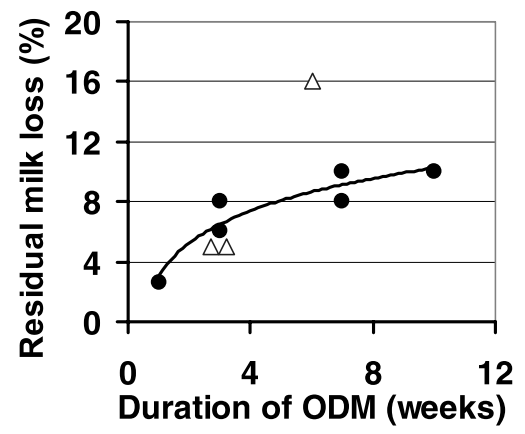

Figure 3. Effect of the duration of once daily milking (ODM) and stage of lactation at which ODM was implemented ( $\Delta$ from calving; from peak of lactation or later) on the residual milk loss after reverting to twice daily milking (from [8, 28, 29, 31, 33, 34]). 


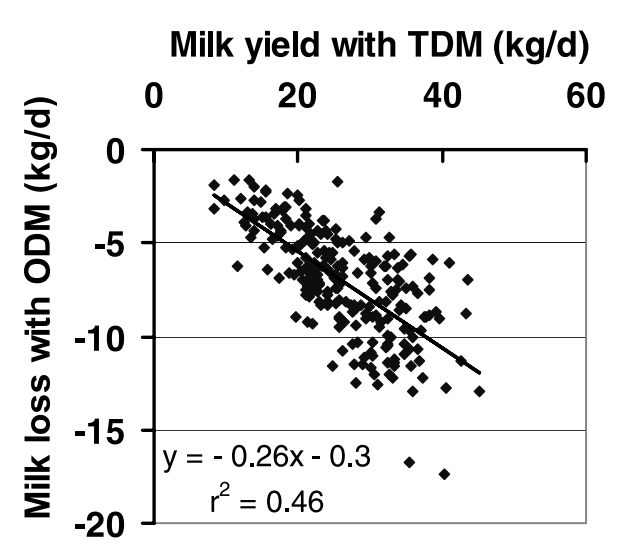

Figure 4. Between-cow variability in the loss of milk yield induced by once daily milking (estimated by the difference between the yield of milk in the last week of twice daily milking and the first week of once daily milking; 237 individual data in the declining phase of lactation).

However, our results showed similar persistencies of milk yield from ODM and TDM cows (parallel or similar curves of milk secretion). According to Vetharaniam et al. [45], the accelerated loss of alveoli would be compensated for by a better energy status of the cows. The expected positive relationship between the amount of mammary parenchyma and the persistency of lactation yield has only been observed occasionally [39].

These general effects of ODM on milk yield were influenced by various factors.

\subsubsection{Level of milk yield}

Following compilation of all our individual data $(n=237)$ recorded in cows switched from TDM to ODM during the declining phase of lactation, milk loss $\left(\mathrm{kg} \cdot \mathrm{d}^{-1}\right)$ between the last week of TDM and the first week of ODM was linearly and significantly related to the milk yield of the cows, with a large between cow variability (Fig. 4). In contrast, the relative loss of production ( $27 \%$ on average) was unrelated to milk yield $\left(r^{2}=0.0002\right)$. A high variability in milk loss has been observed previously $[5,10,21]$. Both positive [18] and negative $[10,21]$ relationships between percentage loss of milk due to ODM and the level of milk yield of the cow have been observed. This can be explained by the low number of cows used in the experiments and the large between cow variations.

\subsubsection{Breed}

The effect of breed on the milk loss induced by ODM was not reproducible. Compared to the loss $(\%)$ in Holstein cows, loss in Montbéliarde cows was significantly lower in one trial (15\% vs. $23 \%$; [28]), whereas it was identical (26\%) in another trial [29] and tended to be higher (28\% vs. $24 \%$ ) in a further trial [29]. With breeds (Friesian and Jersey) and strains exhibiting contrasting milk composition (fat and protein content) and milk storage ability of the udder (hours' worth of secretion [13]), a higher tolerance of Jersey cows to ODM was not clearly established [7, 14]. With the breeds used in our trials, which have relatively similar milk composition and milk yield, the lack of difference in the sensitivity to ODM is not surprising.

\subsubsection{Parity}

In two trials conducted throughout the entire lactation period, milk yield of ODM cows decreased by the same quantity $\left(\mathrm{kg} \cdot \mathrm{d}^{-1}\right)$ in primiparous and multiparous cows (Tab. I). In percentage terms, there was a relatively higher decrease in primiparous cows. In one short trial (3 weeks [31]), the relative decreases in milk yield due to ODM did not differ between primiparous and multiparous cows. Unfortunately, we have no comparative data on the effect of ODM on primiparous and multiparous cows for this management strategy being initiated in the declining phase of lactation versus at calving. A higher sensitivity of primiparous animals to reduced milking frequency has generally been observed, in both cows $[10$, 
Table I. Effect of the parity of the cows on the milk yield loss induced by ODM implemented from calving.

\begin{tabular}{lccccc}
\hline References & $\begin{array}{c}\text { Duration of ODM imple- } \\
\text { mentation (week) }\end{array}$ & $\begin{array}{c}\text { Parity of the cows } \\
\text { (number of cows) }\end{array}$ & $\begin{array}{c}\text { TDM } \\
\left(\mathrm{kg} \cdot \mathrm{d}^{-1}\right)\end{array}$ & \multicolumn{2}{c}{ ODM effect } \\
\hline$[31]$ & 3 & $\mathrm{P}(15)$ & 20.9 & -4.4 & -21 \\
& & $\mathrm{M}(50)$ & 29.8 & -7.2 & -24 \\
{$[8]$} & entire lactation* & $\mathrm{P}(87)$ & 27.4 & -11.8 & -43 \\
& & $\mathrm{M}(40)$ & 33.3 & -11.1 & -33 \\
{$[17]$} & entire lactation & $\mathrm{P}(16)$ & 20.7 & -7.0 & -34 \\
& & $\mathrm{M}(34)$ & 26.2 & -7.3 & -28 \\
\hline
\end{tabular}

* Milk yield calculated on the first 18 weeks of lactation.

$\mathrm{P}=$ primiparous cows; $\mathrm{M}=$ multiparous cows.

References [17] and [31]: cows in ODM and TDM groups received the same diet; reference [8]: cows in ODM group received less concentrate.

47] and goats [38]. Higher development of the udder (cellular multiplication [20], enlargement of the size of the cisterns) in the first lactation compared to the following lactations could be responsible for this higher sensitivity.

\subsubsection{ODM for the first three entire lactations}

Implementation of ODM in the same cows for the first 3 lactations (30 cows in lactation 1, 23 cows in lactation 2 and 17 cows in lactation 3 ) reduced milk yield compared to TDM by a similar quantity at each lactation $(11.6 \mathrm{~kg}, 10.7 \mathrm{~kg}$ and $11.5 \mathrm{~kg}$ for lactations 1, 2 and 3, respectively, on average for the first 18 weeks of lactation; [8]). The decrease in milk yield in primiparous cows $(47 \%)$ was similar to that observed by Claesson et al. [10], and the decreases for lactations 2 and $3(35 \%$ and $32 \%$, respectively) were similar to those recorded in trials where multiparous cows were milked once-daily for the first time $35 \%$ for Holmes et al. [18]; 35\% for Cooper [11]; $30 \%$ for Rémond et al. [35]). From one lactation to the next, the increase in average daily milk yield was similar in ODM and TDM cows $(11.3 \mathrm{~kg}$ and $11.2 \mathrm{~kg}$, respectively, between the 1 st and the 3rd lactation). This means that ODM has no cumulative negative impact on the udder's milk production capacity. It thus appears that the dry period that follows lactation is capable of neutralising the ODM-induced modifications in the udder, as previously observed (Claesson et al. [10] after ODM over the whole lactation period; O'Brien et al. [27] after ODM for the last 2 months of lactation). We observed that the dry period following a lactation where milk yield had been reduced by $22 \%$ following a preceding reduced or omitted dry period is able to completely regenerate the udder's capacity for milk production [30].

\subsubsection{Level of feeding}

In most of our trials (and trials whose results have been published), ODM cows were fed in the same manner as TDM cows and, as a consequence, they exhibited a higher energy balance (see below). In a 5-week trial [36], milk loss of ODM cows relative to TDM cows increased from $6.0 \mathrm{~kg} \cdot \mathrm{d}^{-1}$ $(25 \%)$ when ODM cows received the same quantity of concentrate as TDM cows, to $8.1 \mathrm{~kg} \cdot \mathrm{d}^{-1}(34 \%)$ when ODM cows received $2.6 \mathrm{~kg}$ DM less concentrate, meaning that energy balances were approximately the same for both milking frequencies. There has so far been relatively little analysis of the effect of the level of feeding on the milk 
response of cows to ODM, despite its practical importance. Farmers implementing ODM will be tempted to reduce the level of feeding of their animals (lower concentrate allowance, higher stocking rate at grass) but responses in the short and long term remain unknown. In literature analysis, care should be taken to know the feeding conditions on which milking frequencies were compared.

\subsection{Milk composition}

\subsubsection{Chemical composition}

In agreement with studies reported by Davis et al. [13], ODM almost always increased (significantly or not) the fat and protein content in milk, and decreased the lactose content, by an average of $2.8 \mathrm{~g} \cdot \mathrm{L}^{-1}$, $1.5 \mathrm{~g} \cdot \mathrm{L}^{-1}$ and $1.5 \mathrm{~g} \cdot \mathrm{L}^{-1}$, respectively (means for 10 studies). As a consequence, the ODM-induced decreases in the quantities of fat and proteins secreted were reduced by $4-5$ percentage points compared to the decrease in milk yield. Once TDM was resumed, milk composition was almost always completely restored to control cow levels within 1-2 weeks. In 8 comparisons (6 trials; $[8,28,31-33,35])$, the increase in (true) protein content $\left(1.8 \mathrm{~g} \cdot \mathrm{L}^{-1}\right.$, on average) caused by ODM was due both to casein $\left(1.0 \mathrm{~g} \cdot \mathrm{L}^{-1}\right)$ and whey proteins $\left(0.8 \mathrm{~g} \cdot \mathrm{L}^{-1}\right)$. IgG1 and serum albumin content were increased by $30-40 \%$ [31, 32, 35]. The increased protein content of ODM milk could be related both to a "concentration effect" (lower milk yield) and to the higher energy balance of the cows [12]. The relatively high increase in whey protein concentration, which has frequently been observed [1, 10, 22, 27] is probably due to the increasing tight junction permeability following $18 \mathrm{~h}$ of milk accumulation [44]. The contribution of casein $(56 \%)$ to the increase in true protein content was, therefore, lower than the casein/protein ratio in the milk secreted by TDM cows (around $82 \%$ ). Consequently, ODM resulted in a systematic decrease in the casein/(true) pro-
Table II. Effect of ODM on the protease and lipoprotein lipase activities in milk, and the free fatty acid (FFA) content.

\begin{tabular}{|c|c|c|c|c|}
\hline References & Item & TDM & ODM & $\mathrm{n} 1 / \mathrm{n} 2$ \\
\hline $\begin{array}{l}{[32,33,} \\
35]\end{array}$ & $\begin{array}{l}\text { Protease activity } \\
\text { plasmin } \\
\text { plasminogen }\end{array}$ & $\begin{array}{c}4.4 \\
28.9\end{array}$ & $\begin{array}{c}4.5 \\
34.6\end{array}$ & $\begin{array}{l}0 / 4 \\
2 / 4\end{array}$ \\
\hline$[32,35]$ & LPL activity & 785 & 567 & $0 / 3$ \\
\hline & FFA content & & & \\
\hline$[8,28,33]$ & $0 \mathrm{~h}$ & 0.17 & 0.06 & $3 / 3$ \\
\hline [8] & $24 \mathrm{~h}$ & 0.36 & 0.14 & $1 / 1$ \\
\hline
\end{tabular}

Means were calculated with the results of the different trials.

$\mathrm{n} 1$ : number of comparisons for which the differences between ODM and TDM were significant; $\mathrm{n} 2$ : number of comparisons.

Protease activity is expressed as a variation of optical density. Lipoprotein lipase activity is expressed as $\mathrm{nmol} \cdot \mathrm{min}^{-1} \cdot \mathrm{mL}^{-1}$ (method of analysis in Ref. [32]). Free fatty acid content was measured in just harvested milk $(0 \mathrm{~h})$ and after $24 \mathrm{~h}$ storage at $4{ }^{\circ} \mathrm{C}$. It is expressed as $\mathrm{g}$ of oleic acid per $100 \mathrm{~g}$ fat.

tein ratio, of $1.8 \%$ on average, which is consistent with the general trend $[10,27]$.

\subsubsection{Enzymatic activities}

Plasmin activity in milk was similar for ODM and TDM cows (Tab. II). In the same milk samples, plasminogen-derived activity was arithmetically higher by $20 \%$ (on average; NS) in the ODM cows. This tendency towards a higher protease activity in ODM milk, mainly concerning plasminogen $[22,27]$, has been previously observed $[19,24,43]$, and is in agreement with our results.

Lipoprotein lipase (LPL) activity in the milk of ODM cows was numerically lower (by 28\%) compared to TDM cows (Tab. II). In ODM cows, free fatty acid content in just-harvested milk was $65 \%$ lower than in TDM cows, and lipolysis (measured by the release of FFA after $24 \mathrm{~h}$ at $4{ }^{\circ} \mathrm{C}$ ) was lower by $56 \%$ (Tab. II). To date, the impact of ODM on LPL activity has never been measured. Azzara and Dimick [2] observed an 
increase in LPL activity in the milk of goats milked hourly after oxytocin administration, an observation they attributed to the increased permeability of tight junctions. In the case of ODM - which also augments tight junction permeability - the decreases in LPL activity and FFA content in milk could both result from the large supply of precursors of short-chain fatty acids to the udder (acetate and 3-hydroxy-butyrate) relative to the reduced capacity of fat secretion of the udder. This would induce a lower LPL synthesis by mammary epithelial cells and a decrease in long-chain fatty acid absorption from the blood by the udder. Unfortunately, in our trials we did not measure the fatty acid composition of the milk fat, and evidence for a reduced activity of LPL of mammary blood capillaries is lacking.

\subsubsection{Technological properties}

Milk from ODM cows (richer in proteins by $3 \mathrm{~g} \cdot \mathrm{L}^{-1}$ than milk from TDM cows, but with the same $\mathrm{pH}$; [28]) exhibited a longer coagulation time (13.6 min vs. $11.7 \mathrm{~min}$, $P<0.05)$ and a higher curd firmness (39.1 mm vs. $35.6 \mathrm{~mm}$, respectively; $P<$ 0.05 ) (8 repetitions, measured on a Formagraph device). Both probably resulted from the higher protein (casein) content of milk from ODM cows [26]. For the 8 cheeses prepared with the milk from TDM and ODM cows, after 3.5 months of ripening, none of the 16 descriptors of yield, chemical composition, colour, texture, and sensory characteristics (assessed by a panel) were different, with the exception of a yellow index which tended to be higher $(P<$ $0.10)$ in cheeses made with milk from ODM cows. In a similar approach (using a Formagraph device) with milk from ODM and TDM cows, O'Brien et al. [27] observed no differences in coagulation time or curd firmness between milks from ODM and TDM cows, but the observed difference in casein content $\left(0.8 \mathrm{~g} \cdot \mathrm{kg}^{-1}\right)$ between milk from ODM and TDM cows was much lower than in our experiment $\left(2.2 \mathrm{~g} \cdot \mathrm{L}^{-1}\right)$.

\section{FOOD INTAKE, NUTRITIONAL INDEXES AND REPRODUCTION}

\subsection{Food intake}

The effect of ODM on the cows' capacity of intake can only be evaluated in trials where ODM and TDM cows received the same diet (complete ration ad libitum, or pasture) or the same quantity of concentrate and a forage given ad libitum. In our trials, ODM either had no effect or a low, non-significant effect on food intake (Tab. III). The literature data on this topic remain scarce, probably because most data were recorded using cows grazed on pasture, making intake measurements (or evaluation) difficult. O'Brien et al. [27] did not observe any effect of ODM on intake, whereas Holmes et al. [18] observed that ODM decreased grass intake. Because of the limited duration of ODM in most of our trials, or the turn out of the cows to pasture in the springtime, the comparison of food intake between ODM and TDM was probably not long enough. It has been previously observed that changes in milk yield (as a result of GH administration or drying-off omission in late pregnancy), and thus changes in the nutritional requirements of the cows, were accompanied by an adaptation of the food intake, but only progressively and after a lag-time of at least 6 weeks $[9,30]$. Indeed, one trial (Tab. III; [35]), in which measurements were made for 14 weeks after calving, showed that food intake was identical between ODM and TDM cows for the first 6 weeks of lactation, and then became lower in ODM cows, with the difference reaching $2 \mathrm{~kg}$ DM in week $14(P=0.08)$. This reduction in feed intake was expected. Otherwise, ODM - which decreases milk yield by about 30\% - implemented over the whole lactation in high-producing cows $(7000 \mathrm{~kg}$ per lactation) would increase energy balance by around $1500 \mathrm{Mcal}$ of net energy, i.e. $200 \mathrm{~kg}$ liveweight. In a trial conducted throughout lactation where cows had received the same complete diet in the barn and at pasture in the summer, the difference 
Table III. Effect of ODM on food intake (same diet fed to ODM and TDM cows).

\begin{tabular}{|c|c|c|c|c|c|}
\hline References & $\begin{array}{l}\text { ODM duration } \\
\quad \text { (week) }\end{array}$ & $\begin{array}{l}\text { Period* } \\
\text { (week) }\end{array}$ & $\begin{array}{c}\text { TDM } \\
\left(\mathrm{kg} \mathrm{DM} \cdot \mathrm{d}^{-1}\right)\end{array}$ & $\begin{array}{l}\text { ODM effect } \\
\left(\mathrm{kg} \mathrm{DM} \cdot \mathrm{d}^{-1}\right)\end{array}$ & $\begin{array}{c}\text { Significance } \\
(P)\end{array}$ \\
\hline \multicolumn{6}{|c|}{ ODM from calving } \\
\hline [31] & 6 & $1-6$ & 19.9 & -0.4 & $>0.10$ \\
\hline [32] & 3 & $2-3$ & 15.7 & 0 & $>0.10$ \\
\hline \multirow[t]{3}{*}{ [35] } & entire lactation & $2-6$ & 19.5 & -0.2 & $>0.10$ \\
\hline & & $7-14$ & 21.5 & -1.3 & $>0.10$ \\
\hline & & 14 & 22.0 & -2.0 & 0.08 \\
\hline \multicolumn{6}{|c|}{ ODM in the declining phase } \\
\hline [29] & 3 or 10 & 3 or 10 & 6.0 & -0.5 & $<0.05$ \\
\hline [36] & 5 & 2 & 7.2 & -0.3 & $>0.10$ \\
\hline
\end{tabular}

* Period on which feed intake was calculated, defined by the first and last week after calving for studies starting at calving $([31,32,35]$ : first two lines), or the number of the week after calving (study [35], last line), or the duration (studies $[29,36]$ ).

In studies [31, 32 and 35], all cows received, during the winter period, the same total mixed ration ad libitum. In studies [29 and 36], all cows received the same quantity of concentrate and the same limited quantity of one forage. The other forage (for which results are reported) was fed ad libitum.

in liveweight after 36 weeks of lactation was "only" $56 \mathrm{~kg}$ [35]. Adjustment of intake to lower requirements could be facilitated at pasture, where cows have to harvest their feeds.

\subsection{Live-weight, body condition, energy balance}

When implemented from calving, ODM systematically reduced the duration and extent of live-weight and body score decreased at the beginning of lactation (Tabs. IV and V). These differences between ODM and TDM groups became more significant as ODM duration was extended [31]. The calculated energy balance of ODM cows was less negative or more positive compared to that of TDM cows [31, 32]. The differences in live-weight, body condition and energy balance between ODM and TDM cows increased beyond the period of ODM (3 or 6 weeks in our trials; [31]) probably due to the fact that the residual effect of ODM on milk yield was not (sufficiently) compensated for by a decrease in food intake. Differences in the changes in liveweight and body condition scores appear to stabilise when ODM is implemented throughout lactation (Fig. 5). In agreement with these changes, plasma from ODM cows has a higher glucose content $\left(+0.1 \mathrm{~g} \cdot \mathrm{L}^{-1}\right)$ and lower NEFA content $\left(-0.27 \mathrm{mmol} \cdot \mathrm{L}^{-1}\right)$ than in TDM cows [31]. In early lactation, the lower number of cows suffering from milk fever in the ODM (1 out of 42) group than in the TDM group (7 out of 31 ) probably reflects the better mineral status of

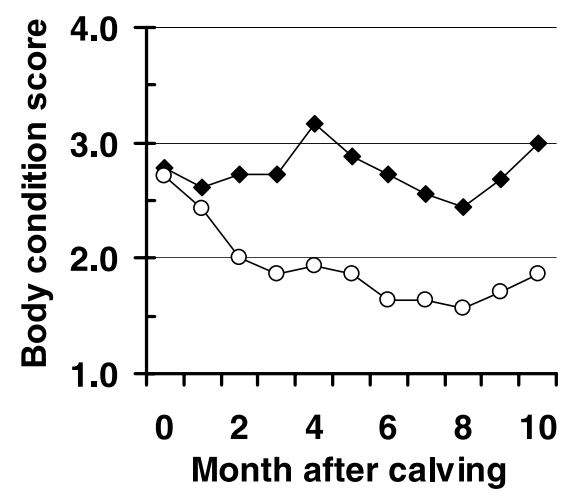

Figure 5. Changes in body condition score (range: $0-5$ ) of cows milked once daily (ODM: $\diamond)$ or twice daily (TDM: o) throughout lactation (from [35]; 16 cows in total). 
Table IV. Effect of ODM on live weight change (kg).

\begin{tabular}{|c|c|c|c|c|c|}
\hline References & $\begin{array}{l}\text { ODM duration } \\
\text { (week) }\end{array}$ & $\begin{array}{l}\text { Period* } \\
\text { (week) }\end{array}$ & $\begin{array}{l}\text { Live weight change }(\mathrm{kg}) \\
\text { ODM group }\end{array}$ & $\begin{array}{l}\text { Live weight change } \\
\text { (kg) TDM group }\end{array}$ & Significance \\
\hline \multicolumn{6}{|c|}{ ODM from calving } \\
\hline \multirow[t]{2}{*}{ [32] } & 3 & $3-1$ & -4.2 & -15.1 & 0.11 \\
\hline & & $16-1$ & 1.7 & -34.3 & $<0.01$ \\
\hline \multirow[t]{2}{*}{ [30] } & 6 & $6-1$ & -14.8 & -25.7 & 0.23 \\
\hline & & $11-1$ & 7.4 & -25.7 & 0.01 \\
\hline \multirow[t]{3}{*}{ [35] } & entire lactation & $6-1$ & -8.5 & -23.3 & 0.09 \\
\hline & & $12-1$ & 3.0 & -20.1 & 0.09 \\
\hline & & $34-1$ & -28.8 & -88.2 & $<0.01$ \\
\hline \multicolumn{6}{|c|}{ Declining phase of lactation } \\
\hline$[28,33]$ & 7 & $7-1$ & 16.5 & 11.4 & 0.22 \\
\hline [29] & 3,10 & $(3$ or 10$)-1$ & 8.0 & 5.1 & 0.46 \\
\hline
\end{tabular}

* First and last week of the period on which live weight change was calculated: number of the week after calving for the trials beginning at calving; number of the week in the trial for the trials carried out in the declining phase of lactation.

Table V. Effect of ODM on the change in body condition (point of score in a $0-5$ scale).

\begin{tabular}{lccccc}
\hline References & $\begin{array}{c}\text { ODM duration } \\
(\mathrm{wk})\end{array}$ & $\begin{array}{c}\text { Period* } \\
\text { (week) }\end{array}$ & ODM & TDM & $\begin{array}{c}\text { Significance of the } \\
\text { difference }\end{array}$ \\
\hline \multirow{5}{*}[32]{} & 3 & $1-3$ & -0.19 & -0.39 & $<0.01$ \\
& & $1-12$ & -0.65 & -1.16 & $<0.01$ \\
{$[31]$} & 3 & $11-1$ & -0.8 & -1.3 & $>0.10$ \\
& 6 & $11-1$ & -0.5 & -1.3 & 0.10 \\
{$[35]$} & Entire lactation & $4-1$ & -0.17 & -0.29 & $>0.10$ \\
& & $13-1$ & -0.05 & -0.86 & 0.02 \\
{$[17]$} & 44 & $44-1$ & 0.02 & -1.02 & $<0.01$ \\
& & $4-1$ & 0.5 & -0.5 & n.c. \\
{$[33]$} & 7 & Declining phase of lactation & & $>0.10$ \\
{$[28]$} & 7 & $7-1$ & 0.4 & 0.3 & $>0.10$ \\
\hline
\end{tabular}

* First and last week of the period on which change of body condition was calculated: number of the week after calving for the trials beginning at calving; number of the week in the trial for the trials in the declining phase of lactation.

n.c. $=$ not calculated.

ODM cows, related to their lower milk secretion $[31,32]$.

When ODM was implemented for a few weeks during the declining phase of lactation, the changes in live-weight and body condition scores followed similar but less pronounced and often non-significant trends
(Tabs. IV and V). This may be related to the more limited impact of ODM on milk yield in the declining phase of lactation than throughout the entire lactation. The lack of grass intake measurements during these trials compromises the interpretation of these observations. These impacts of ODM 
Table VI. Effect of ODM on some parameters of reproduction.

\begin{tabular}{lcccc}
\hline References & Item & ODM & TDM & Significance \\
\hline$[35]$ & Pregnant cows at 102 d after calving / & $8 / 9$ & $4 / 7$ & \\
total no of cows & & & \\
{$[8]$} & Calving - 1st cycle (d) & 24.3 & 28.0 & NS \\
& Calving - 1st oestrus (d) & 49.7 & 69.4 & $<0.05$ \\
& Calving - successful AI (d) & 105.4 & 129.0 & 0.04 \\
& No of AI per cow & 1.68 & 1.94 & NS \\
{$[17]$} & Calving - 1st oestrus (d) & 35 & 41 & n.c. \\
& Calving - successful AI (d) & 85 & 102 & \\
& Success (A.I. 1 + A.I. 2) (\%) & 80 & 68 & \\
\hline
\end{tabular}

Reference [8]: 87 primiparous cows; reference [17]: 50 cows.

$\mathrm{AI}=$ artificial insemination; n.c. $=$ not calculated.

on the nutritional status of the cows have been widely observed, whether they concern liveweight or body condition $[10,11$, $18,25,27]$ or blood profile [1].

\subsection{Reproduction}

In 3 trials where ODM was implemented from calving, the parameters that characterise reproduction were generally numerically improved (Tab. VI). This is probably related to the more positive (or less negative) energy balance of the cows [4]. Data on the impact of ODM on reproduction are scarce, however, since few trials have targeted the early lactation period. With 65 cows, Cooper [11] did not record any effect of ODM on the calving-first ovulation interval but observed an increased calving-first oestrus interval, which she attributed to the fewer opportunities for observing the cows at milking for oestrus signs. In a study with 10 herds, Rhodes et al. [37] observed that implementation of ODM for 1 month around the period of mating significantly increases the proportion of cows in oestrus but tends to decrease the conception rate to first insemination, for an unknown reason. Moreover, the data should be regarded with caution since reproduction studies require a large number of animals.

\section{ADAPTATION OF COWS TO ODM AND UDDER HEALTH}

\subsection{Adaptation of the cows}

According to our mostly unplanned observations, the cows appeared to adapt rapidly to ODM. In the declining phase of lactation, at pasture (ODM and TDM cows grazed different, distant fields), the first omission of milking was accompanied by increased vocalisation, which was more pronounced in Montbéliarde cows than in Holsteins [28]. During the morning of the following day, the cows were anxious to enter the milking parlour, with some cows exhibiting milk leakage from the udder. From the second evening onwards, they seemed to have become completely accustomed to the ODM regime, to such a degree that their milk yield was low on the first evening's milking after TDM resumption. Indoors, ODM and TDM cows were in the same free-stall barn, but sorting the cows just before the evening milking to prevent ODM cows from entering the milking parlour never posed a problem, according to the cow-handlers. Nevertheless, behaviours attributable to manifestations of discomfort have been observed in cows on ODM regimes. In early lactation, ODM cows vocalised more than TDM cows around the evening milking (3.2 vocalisations per cow per h vs. 0.2 before milking, 
and 1.6 vs. 0.1 after milking; [32]). Vocalisation of ODM cows was the highest ( 8.7 vocalisations per cow per $h$ ) during the milking of TDM cows. Before the morning milking, the numbers of vocalisations were not significantly different between ODM and TDM cows (3.6 vs. 1.3 vocalisations, respectively), but the number of cows whose udder leaked was higher in ODM cows (9/10 vs. 5/10). In two trials carried out in Brittany (50 cows per trial), Brulé et al. [3] observed that during very early lactation, udder oedema was more prevalent in ODM cows. The cows spent more time standing up before milking, were more restless during milking, and the cortisol content in their milk was significantly higher. These particularities decreased later in lactation, and were not evident when cows in early lactation were grazing pasture.

These results, recorded under experimental conditions, contrast with the observations reported by private farmers. In a survey of 121 private French farms where ODM had been used for 9 weeks on average (mainly to adjust the milk yield of the herd to the milk quota allocated to the farm), all farmers said they had been satisfied with ODM, and that their cows had rapidly adapted [16]. It is likely that, under experimental conditions, there is an increase in manifestations liable to be interpreted as signs of discomfort. ODM cows were housed in the same barns as TDM cows. They were able to observe the routine of milking (noises, view of the milker and of the TDM cows moving to the milking parlour), which is not the case either in cows on pasture or on private farms where ODM is implemented on all cows. We have indeed observed that the number of vocalisations by ODM cows decreased 5-fold when the TDM cows returned from the milking parlour to the common loose-house barn after milking ([32]; see above). Hence, vocalisations seem to be manifestations of social stress (disruption of the herd) rather than signs of pain or discomfort. Thus, the observations made on experimental farms probably give an exac-
Table VII. Effect of ODM on the somatic cell count (SCC) in milk $(\times 1000)$, or the proportion of milk samples exhibiting a SCC lower than 300000 per mL (Ref. [17]).

\begin{tabular}{|c|c|c|c|}
\hline $\begin{array}{l}\text { References } \\
\text { (No. of cows) }\end{array}$ & TDM & ODM & Significance \\
\hline \multicolumn{4}{|c|}{ Short period (1-10 weeks) in declining phase } \\
\hline $\begin{array}{l}{[33,28,34,29]} \\
(214)\end{array}$ & 91 & 123 & $\begin{array}{l}3 \text { trials: NS } \\
2 \text { trials: HS }\end{array}$ \\
\hline \multicolumn{4}{|c|}{ Long period from calving (> $18 \mathrm{wk}$ ) } \\
\hline [35] (16) & 88 & 110 & NS \\
\hline [8] (88) & 65 & 122 & $<0.01$ \\
\hline [17] (50) & $80 \%$ & $68 \%$ & n.c. \\
\hline
\end{tabular}

NS: not significant; HS: highly significant; n.c.: not calculated.

Reference [35]: SCC differed significantly between ODM and TDM groups $(0.05<P<$ 0.10 ) for 7 of the last 15 weeks of the lactation, the mean for ODM group reaching 400000 cells per $\mathrm{mL}$ in the last weeks.

Reference [8]: primiparous cows only.

erbated image of the stress inherent to the change in milking regime.

\subsection{Somatic cell count and mastitis occurrence}

Change from TDM to ODM in the declining phase of lactation led to an increased SCC in the milk in each of our 5 trials, all carried out with cows on pasture $[28,29,33$, 34], by 32000 per mL on average (Tab. VII). This higher (significantly or not) SCC induced by ODM, observed often [11, 18, $19,25,27,40]$ but not always [23, 24, 43], did not result from a higher incidence of mastitis, neither in our trials (Tab. VIII), nor in most foreign trials (see above references). The elevated SCC probably resulted from the increasing but transient tight junction opening of the secretory epithelium of alveoli from about 18 hours after the previous milking [44] until the following milking. Resumption of TDM eliminated the differences between both milking regimes (difference of 400 somatic cells per $\mathrm{mL}$, on average; Tab. VII). 
Table VIII. Mastitis frequency during the period of ODM implementation (number of cows concerned or number of mastitis incidences/total number of cows, or number of interventions).

\begin{tabular}{lccccc}
\hline Reference & $\begin{array}{c}\text { ODM duration } \\
(\mathrm{wk})\end{array}$ & $\begin{array}{c}\text { Item } \\
(\text { number })\end{array}$ & $\begin{array}{c}\text { ODM } \\
\text { group }\end{array}$ & $\begin{array}{c}\text { TDM } \\
\text { group }\end{array}$ & Significance \\
\hline$[33]$ & 7 & cows (18) & $0 / 9$ & $0 / 9$ & n.c. \\
{$[28]$} & 7 & cows (64) & $2 / 32$ & $2 / 32$ & n.c. \\
{$[34]$} & 1 & cows (18) & $0 / 9$ & $0 / 9$ & n.c. \\
{$[29]$} & 3 or 10 & cows (54) & $0 / 27$ & $0 / 27$ & n.c. \\
{$[29]$} & 3 & cows (54) & $0 / 27$ & $0 / 27$ & n.c. \\
& & & Long term & & \\
{$[35]$} & 40 & mastitis & $1 / 9$ & $1 / 7$ & n.c. \\
{$[8]$} & 18 & cows (87) & $10 / 37$ & $5 / 50$ & 0.04 \\
{$[17]$} & 40 & interventions & $\times 3.5^{*}$ & & n.c. \\
\hline
\end{tabular}

n.c.: not calculated.

Reference [17]: 3.5 times more interventions for mastitis problems in the ODM group in comparison with the TDM group.

When ODM was implemented from calving on short-term experiments, SCC did not increase [31,32]. Progressive development in early lactation of secretory tissue [20], milk secretion and the udder's milk capacity may explain the lack of (the lower) permeability of tight junctions. Both of our trials over the entire lactation period showed a higher SCC in ODM milk compared to TDM (from week 7 of lactation [8] and from week 30 [35]). In this last trial [35], the higher SCC in milk produced by ODM cows could not be attributable to a higher occurrence of mastitis (one for each milking regime), but possibly to the lower milk yield and the higher proportion of pregnant cows in this group. SCC levels reported by Holmes et al. [18] showed the same trend in SCC, without a higher incidence of mastitis. In the first trial [8], mastitis was more frequent in ODM cows, which was also observed in a trial in Brittany carried out over the whole lactation period (Tab. VIII; [17]). In both of these trials, the first months of lactation took place indoors where milk leakages from the udder were observed. In long-term experiments at pasture, Holmes et al. [18] and Cooper [11] did not record an increased occurrence of mastitis or infected quarters. Thus, it is possible that frequency of mastitis occurrence and therefore SCC are favoured indoors in an ODM context due to bacterial spoilage of the bedding area resulting from milk leakage from the udder.

\section{CONCLUSION}

Our results are relatively consistent and allow to better evaluate, in our conditions, the impacts of ODM on performance (e.g. milk yield) and animals (nutritional status, well-being, udder health). The ODM practice inevitably resulted in a noticeable decrease in individual milk yield. This decrease can be more or less comfortably endured and compensated for by the farmer, according to the duration of ODM and the characteristics of the farm (e.g. availability in pastures, and places in the cowshed allowing an increased number of cows). This practice could improve the sustainability of the milk production system through a larger utilisation of fresh or preserved forages in the cow's diet. 
- In the short and medium-term (a few days to 2-3 months), and during the declining phase of lactation, ODM decreases milk yield by around $25 \%$ when feeding level is not reduced. ODM appears to be safe, even if it increases SCC in a generally acceptable manner, at least in healthy herds. In early lactation, the impacts of ODM are more pronounced and depend on the duration of ODM, both during ODM implementation and once TDM is resumed, and could provoke some transient discomfort in cows and milk leakages.

- In the long-term (entire lactation period), milk losses and health hazards are higher. Individual differences in milk losses open the possibility for selecting cows that are less sensitive to ODM; studies are in progress. Concerning the risk of mastitis, factors determining mastitis occurrence need to be better identified and evaluated. Indoor management could carry more risks for the incidence of mastitis. Other aspects also require further study, such as the consequences on milk processing.

To progress more rapidly in many aspects relating to ODM, the detailed monitoring of the performance of farms implementing ODM and manufacturers using ODM milk should enable to better identify the issues for investigation.

\section{REFERENCES}

[1] Auldist M.J., Prosser C.G., Differential effects of short-term once-a-day milking on milk yield, milk composition and concentration of selected blood metabolites in cows with high or low pasture intake, Proc. N.Z. Soc. Anim. Prod. 58 (1998) 41-43.

[2] Azzara C.D., Dimick P.S., Paracellular leakage of lipoprotein lipase across the mammary epithelium of the goat, J. Dairy Sci. 72 (1989) $1159-1168$.

[3] Brulé A., Brocard V., Portier B., Racine V., Effets de la réduction de la fréquence de traite sur le bien-être de la vache laitière, Renc. Rech. Rum. 10 (2003) 77-80.
[4] Butler W., Nutritional interactions with reproductive performance in dairy cattle, Anim. Reprod. Sci. 60-61 (2000) 449-457.

[5] Carruthers V.R., Davis S.R., Bryant A.M., Morris C.A., Selection of cows for once a day milking, Proc. Ruakura Farmer's Conf. (1989) 12-14.

[6] Carruthers V.R., Davis S.R., Norton D.H., The effects of ocytocin and bovine somatotropin on production of cows milked once a day, Proc. N.Z. Soc. Anim. Prod. 51 (1991) 197201

[7] Carruthers V.R., Davis S.R., Bryant A.M., Henderson H.V., Morris C.A., Copeman P.J.A., Response of Jersey and Friesian cows to once a day milking and prediction of response based on udder characteristics and milk composition, J. Dairy Res. 60 (1993) 111.

[8] Chauvin L., Effets de la traite une fois par jour pendant l'ensemble de la lactation des vaches laitières prim'holstein, chez les primipares et durant trois lactations successives, Thèse diplôme d'état de Docteur Vétérinaire, 20 janvier 2005, Faculté de Médecine de Nantes, $112 \mathrm{p}$.

[9] Chilliard Y., Review. Long-term effects of recombinant bovine somatotropin (rBST) on dairy cow performances, Ann. Zootech. 37 (1988) 159-180.

[10] Claesson O., Hansson A., Gustafsson N., Brannang E., Studies on monozygous cattle twins. XVII. Once-a-day milking compared with twice a day milking, Acta Agric. Scand. 9 (1959) 38-58.

[11] Cooper C., Once-a-day milking: possible and profitable? South Island Dairy Event Proceedings (2000) 152-163.

[12] Coulon J.B., Rémond B., Variations in milk output and milk protein content in response to the level of energy supply to the dairy cow: a review, Livest. Prod. Sci. 29 (1991) 31-37.

[13] Davis S.R., Hughson G.A., Measurement of functional udder capacity in lactating Jersey cows, Aust. J. Agric. Res. 39 (1988) 1163 1168.

[14] Davis S.R., Farr V.C., Stelwagen K., Regulation of yield loss and milk composition during once-a-day milking: a review, Livest. Prod. Sci. 59 (1999) 77-94.

[15] Farr V.C., Stelwagen K., Kerr M.A., Davis S.R., Eichler S.J., Effect of once daily milking (ODM) on enzyme activities in the bovine 
mammary gland, Proc. N.Z. Soc. Anim. Prod. 55 (1995) 12-13.

[16] Guéguen L., Brocard V., Une traite par jour en élevage bovin : recueil de l'expérience de 120 éleveurs français, Renc. Rech. Rum. 10 (2003) 114

[17] Guéguen L., Pomiès D., Rémond B., Ne plus traire qu'une fois par jour, in: Traite et travail ; quelles solutions pour réduire l'astreinte liée à la traite, Collection Journées Techniques, Institut de l'élevage, 2004, pp. 19-26.

[18] Holmes C.W., Wilson G.F., MacKenzie D.D.S., Purchas J., The effect of milking once daily throughout lactation on the performance of dairy cows grazing on pasture, Proc. N.Z. Soc. Anim. Prod. 52 (1992) 13-16.

[19] Kelly A.L., Reid S., Joyce P., Meaney W.J., Foley J., Effect of decreased milking frequency of cows in late lactation on milk somatic cell count, polymorphonuclear leucocyte numbers, composition and proteolytic activity, J. Dairy Res. 65 (1998) 365-373.

[20] Knight C.H., Wilde C.J., Mammary cell changes during pregnancy and lactation, Livest. Prod. Sci. 35 (1993) 3-19.

[21] Knight C.H., Dewhurst R.J., Once daily milking of dairy cows: relationship between yield loss and cisternal milk storage, J. Dairy Res. 61 (1994) 441-449.

[22] Knutson R.J., MacKenzie D.D.S., Davis S.R., McCutcheon S.N., The effect of once daily milking on concentrations and yields of plasminogen, plasmin and other whey proteins, Proc. N.Z. Soc. Anim. Prod. 53 (1993) 155158.

[23] Lacy-Hulbert S.J., Woolford M.W., Bryant A.M., Influence of once daily milking and restricted feeding on milk characteristics in late lactation, Proc. N.Z. Soc. Anim. Prod. 55 (1995) 85-87.

[24] Lacy-Hulbert S.J., Woolford M.W., Nicholas G.D., Prosser C.G., Stelwagen K., Effect of milking frequency and pasture intake on milk yield and composition of late lactation cows, J. Dairy Sci. 82 (1999) 1232-1239.

[25] Lynch G.A., Hunt M.E., Mackenzie D.D.S., The effects of once daily milking as a management practice in late lactation, Proc. N.Z. Soc. Anim. Prod. 51 (1991) 191-195.

[26] Martin B., Coulon J.B., Facteurs de production du lait et caractéristiques des fromages. I. Influence des facteurs de production sur l'aptitude à la coagulation des laits de troupeaux, Lait (1995) 61-80.
[27] O'Brien B., Ryan G., Meaney W.J., McDonagh D., Kelly A., Effect of frequency of milking on yield, composition and processing quality of milk, J. Dairy Res. 69 (2002) 367-374.

[28] Pomiès D., Martin B., Rémond B., Brunschwig G., Pradel P., Lavigne R., Hulin S., La traite une fois par jour pendant 7 semaines de vaches laitières Prim'Holstein et Montbéliardes en milieu de lactation : performances zootechniques, qualité du lait et des fromages, Renc. Rech. Rum. 10 (2003) 81-84.

[29] Pomiès D., Rémond B., Pradel P., Performances des vaches laitières et qualité du lait lors de la monotraite et après retour à deux traites par jour, en fonction de la durée de cette pratique et du stade de lactation des animaux, Renc. Rech. Rum. 11 (2004) 225-228.

[30] Rémond B., Rouel J., Pinson N., Jabet S., An attempt to omit the dry period over three consecutive lactations in dairy cows, Ann. Zootech. 46 (1997) 399-408.

[31] Rémond B., Coulon J.B., Nicloux M., Levieux D., Effect of once-a-day milking in early lactation on milk production and nutritional status of dairy cows, Ann. Zootech. 48 (1999) 341-352.

[32] Rémond B., Aubailly S., Chilliard Y., Dupont D., Pomiès D., Petit M., Combined effects of once-a-day milking and feeding level in the first three weeks of lactation on milk production and enzyme activities, and nutritional status in Holstein cows, Anim. Res. 51 (2002) 101-117.

[33] Rémond B., Pradel P., Pomiès D., Petit M., Effet de la traite une fois par jour, pendant sept semaines, de vaches laitières en milieu de lactation, Renc. Rech. Rum. 9 (2002) 203.

[34] Rémond B., Pomiès D., Brunschwig G., La traite une fois par jour de vaches Prim'Holstein, pendant une semaine, diminue la production laitière de $25 \%$, sans effet rémanent, Renc. Rech. Rum. 10 (2003) 113.

[35] Rémond B., Pomiès D., Dupont D., Chilliard Y., Once-a-day milking of multiparous Holstein cows throughout the entire lactation: milk yield and composition, and nutritional status, Anim. Res. 53 (2004) 201-211.

[36] Rémond B., Pomiès D., Pradel P., Effet de la monotraite des vaches laitières sur leur production, selon le niveau de distribution d'aliments concentrés, Renc. Rech. Rum. 12 (2005) 4 p. (in press).

[37] Rhodes F.M., Clark B.A., MacMillan K.L., McDougall S., Use of once daily milking or treatment with progesterone and oestradiol 
benzoate in anoestrous cows, Proc. N.Z. Soc. Anim. Prod. 58 (1998) 44-46.

[38] Salama A.A.K., Such X., Caja G., Rovai M., Casals R. Albanell E., Marin M.P., Marti A. Effects of once versus twice daily milking throughout lactation on milk yield and milk composition in dairy goats, J. Dairy Sci. 86 (2003) 1676-1680.

[39] Stelwagen K., Effect of milking frequency on mammary functioning and shape of the lactation curve, J. Dairy Sci. 84 (Suppl. E.) (2001) E204-E211.

[40] Stelwagen K., Lacy-Hulbert S.J., Effect of milking frequency on milk somatic cell count characteristics and mammary secretory cell damage in cows, Am. J. Vet. Res. 57 (1996) 902-905.

[41] Stelwagen K., Knight C.H., Effet of unilateral once or twice daily milking of cows on milk yield and udder characteristics in early and late lactation, J. Dairy Res. 64 (1997) 487494.

[42] Stelwagen K., Davis S.R., Farr V.C., Eichler C.J., Politis I., Effect of once daily milking and concurrent somatotropin on mammary tight junction permeability and yield of cows, J. Dairy Sci. 77 (1994) 2994-3002.
[43] Stelwagen K., Politis I., White J.H., Zavizion B., Prosser C.G., Davis S.R., Farr V.C., Effect of milking frequency and somatotropin on the activity of plasminogen activator, plasminogen, and plasmin in bovine milk, J. Dairy Sci. 77 (1994) 3577-3583.

[44] Stelwagen K., Farr V.C., McFadden H.A., Prosser C.G., Davis S.R., Time course of milk accumulation-induced opening of mammary tight junctions, and blood clearance of milk components, Am. J. Physiol. 273 (1997) 379_ 386.

[45] Vetharaniam I., Davis S.R., Soboleva T.K., Shorten P.R., Wake G.C., Modeling the interaction of milking frequency and nutrition on mammary gland growth and lactation, J. Dairy Sci. 86 (2003) 1987-1996.

[46] Wilde C.J., Addey C.V.P., Boddy L.M., Peaker M., Autocrine regulation of milk secretion by a protein in milk, Biochem. J. 305 (1995) 51-58.

[47] Woolford M.W., Copeman P.J.A., Napper A.R., Phillips D.S.M., Williamson J.H., Ulfee E.J., Milking intervals: are changes worthwhile? Proc. Ruakura Farmer's Conf. (1985) 120-128. 